\title{
Association between perineal trauma and pain in primiparous women*
}

\author{
ASSOCIAÇÃO ENTRE TRAUMA PERINEAL E DOR EM PRIMÍPARAS \\ ASSOCIACIÓN ENTRE EL TRAUMA PERINEAL Y DOLÓR EM PRIMÍPARAS
}

\author{
Adriana Amorim Francisco', Mirian Hiromi Kinjo², Caroline de Souza Boscoㄹ, Renata Luana \\ da Silva ${ }^{4}$, Edilaine de Paula Batista Mendes ${ }^{5}$, Sonia Maria Junqueira Vasconcellos de Oliveira ${ }^{6}$
}

\begin{abstract}
Objective: To identify the association between perineal trauma and pain in 473 primiparous women. Method: Cross-sectional study in which pain was measured by the numerical pain scale (0 to 10 - 0 being no pain and 10 maximal pain). Results: The prevalence and mean intensity of pain were $33.0 \%$ and 4.7 points (standard deviation = $2.0)$ in the numeric scale, respectively. Episiotomy represented the most frequent trauma (46.7\%). The occurrence and intensity of the pain were associated with perineal trauma and postpartum time. Having perineal trauma tripled the chance of pain. Each hour elapsed following the birth reduced the chance of pain by $4.8 \%$. Conclusion: Primiparous women are subject to a high frequency of perineal trauma, with episiotomy being the most prominent. Perineal pain affects approximately one-third of primiparous women and is associated with the postpartum time and perineal traumas.
\end{abstract}

\section{DESCRIPTORS:}

Pain

Episiotomy

Parity

Postpartum period

Obstetrical nursing

\section{RESUMO}

Objetivo: Identificar a associação entre trauma perineal e dor em 473 primíparas. Método: Estudo transversal, no qual a dor foi mensurada por meio da escala numérica de dor ( 0 a 10 - sendo 0 ausência de dor e 10 dor máxima). Resultados: A prevalência e a média de intensidade de dor foram $33,0 \%$ e 4,7 (Desvio Padrão $=2,0$ ) pontos na escala numérica, respectivamente. A episiotomia foi o trauma mais frequente $(46,7 \%)$. A ocorrência e a intensidade da dor foram associadas ao trauma perineal e ao tempo de pós-parto. Ter trauma perineal triplicou a chance de dor. Cada hora decorrida depois do parto reduziu a chance de dor em 4,8\%. Conclusão: As primíparas estão sujeitas a elevada frequência de trauma perineal, sobretudo episiotomia. A dor perineal afeta, aproximadamente, um terço das primíparas e está associada ao tempo de pós-parto e aos traumas perineais.

\author{
DESCRITORES: \\ Dor \\ Episiotomia \\ Paridade \\ Período pós-parto \\ Enfermagem obstétrica
}

\begin{abstract}
RESUMEN
Objetivo: Identificar la asociación entre el trauma y el dolor perineal en 473 primíparas. Método: Estudio transversal, en el que el dolor se midió por medio de la escala numérica del dolor ( 0 a 10; 0 = ningún dolor y 10 = dolor máximo). Resultados: La prevalencia y el promedio de intensidad del dolor fueron 33,0\% y 4,7 (Desviación Estándar = $2,0)$ puntos en la escala, respectivamente. La episiotomía fue el trauma más frecuente $(46,7 \%)$. La ocurrencia y la intensidad del dolor se asociaron con el trauma y el tiempo del postparto. Tener trauma perineal triplica la probabilidad de tener dolor. Cada hora transcurrida después del nacimiento reduce la posibilidad de dolor en $4,8 \%$. Conclusión: Las primíparas están sujetas a altas tasas de trauma perineal, especialmente episiotomía. El dolor perineal afecta aproximadamente a un tercio de las primíparas y se asocia con el tiempo de postparto y el traumatismo perineal.
\end{abstract}

DESCRIPTORES:
Dolor
Espisiotomía
Paridad
Período de postparto
Enfermería obstétrica

\footnotetext{
* Extracted from the study "Length of perineal analgesia using cryotherapy: a randomized controlled trial," 1st Showing of Studies of the Postgraduate Nursing Program, School of Nursing, University of São Paulo, 2013. ${ }^{1}$ Doctorate Student, School of Nursing, University of São Paulo, São Paulo - São Paulo, Brazil. ${ }^{2}$ Nurse Graduate from the School of Nursing, University of São Paulo, São Paulo - São Paulo, Brazil. ${ }^{3}$ Masters Degree Student, School of Nursing, University of São Paulo, São Paulo - São Paulo, Brazil. ${ }^{4}$ Masters Degree Student of the School of Nursing, University of São Paulo, São Paulo - São Paulo, Brazil. ${ }^{5}$ Masters Degree Student of the School of Nursing, University of São Paulo, São Paulo - São Paulo, Brazil. ${ }^{6}$ Associate Professor, Department of MaternalInfant and Psychiatric Nursing, School of Nursing, University of São Paulo, São Paulo - São Paulo, Brazil.
} 


\section{INTRODUCTION}

As a result of vaginal birth, most women have a certain extent of perineal trauma, which can be characterized by the occurrence of spontaneous lacerations, episiotomy or both. The rates of occurrence of these injuries vary internationally, especially in relation to episiotomy. In Asian countries such as China and Taiwan, the rate exceeds $82 \%$, while in European countries such as Sweden, Denmark and England, it is between $9.7 \%$ and $13 \%{ }^{(1)}$. In Brazil, the National Survey on Demography and the Health of Women and Children (PNDS - Pesquisa Nacional de Demografia e Saúde da Criança e da Mulher), carried out by way of a national survey that included about 4,000 women, found that in the five years preceding the survey, episiotomy was practiced in $70 \%$ of the births in the country, with smaller proportions found only in women with at least three children ${ }^{(2)}$.

When considering parity, the rates are shown to be even higher. It has been observed that primiparous women are more exposed to perineal trauma ${ }^{(3-4)}$, principally as a result of episiotomy. Women without previous vaginal birth were three times more likely to be subjected to this procedure ${ }^{(5)}$, while among multiparous women the likelihood to undergo such an intervention is $55 \%$ lower $^{(4)}$. In certain South American countries, the proportion of primiparous women who had an episiotomy exceeds $90 \%{ }^{(1)}$. Other data indicates that the rate of this procedure in nulliparous women was on average $44 \%$ higher than that observed in all vaginal deliveries recorded in hospitals in six emerging countries ${ }^{(6)}$.

Therefore, one must consider that episiotomy is associated with complications, including increased risk of posterior perineal trauma, need for suturing, complications in the healing of the wound ${ }^{(7)}$, risk of infection, anal and urinary incontinence ${ }^{(8)}$, dyspareunia and perineal pain ${ }^{(9-10)}$.

Perineal pain is a common symptom among mothers that may occur immediately following birth and persist beyond the postnatal period. A survey conducted with 2,400 women in the United States showed that among 1,656 women who underwent vaginal delivery, $40 \%$ reported perineal pain in the first two months following the delivery. At or after six months, some of them still reported pain in the perineum as a persistent problem ${ }^{(11)}$.

In general, the occurrence and intensity of perineal pain are related to the severity of injury in this region. A study conducted with 215 Australian women 72 hours after vaginal delivery showed that the intensity of perineal pain was significantly affected by the degree of the trauma ${ }^{(12)}$. The survey cited above showed that the severity of the pain was strongly related to the existence of an episiotomy; among mothers with vaginal delivery $7 \%$ reported a painful perineum six months after birth, while for those who had an episiotomy, the rate was $9 \%^{(11)}$.
However, even if the perineum is intact, some women may report pain ${ }^{(12)}$.

Perineal pain is debilitating and affects the mobility of women. Many reported pain when sitting, walking, breastfeeding and while taking care of the baby ${ }^{(12-13)}$. This interference varies from mild to extreme ${ }^{(11)}$ and may negatively impact the experience of motherhood.

Therefore, understanding that the postpartum is a period of many adaptations, especially for women experiencing motherhood for the first time, and being that the perineal pain is a factor that complicates the carrying out of self-care activities, as well as the interaction between the binomial, to investigate whether there is an association between pain and the occurrence of perineal trauma in primiparous women is important in order to offer evidence in an effort to support obstetric care.

The aim of the study was to identify the occurrence of the association between perineal trauma and pain in primiparous women.

\section{METHOD}

A cross-sectional study conducted in the Roomingin Care Unit (RCU) of a philanthropic hospital linked to the Brazilian Unified Health System (Sistema Único de Saúde - SUS), which serves pregnant women with low to medium risk.

In this institution, obstetricians are responsible for leading the care of women admitted to maternity hospitals who have a high risk pregnancy and/or require caesarean section. During labour and spontaneous birth among low risk women admitted to a midwifery-led birth centre, care is provided by midwives and nurse-midwives.

Data collection occurred between December 10, 2012 and February 8, 2013. We included in the study women who gave birth at the institution during this period while also meeting the inclusion criteria: normal delivery; no previous vaginal delivery; pregnancy of single live fetus in a vertex presentation, no spinal or epidural analgesia during labor; no clinical or obstetric complications; no difficulties in communication or understanding of the Portuguese language; and the newborn (NB) in good clinical condition at the time of inclusion in the study.

Perineal pain was measured by the numerical pain scale $^{(14)}$ (0 to 10 - 0 being no pain and 10 maximal pain). The woman was questioned about the occurrence of pain in the perineum, by asking Are you in pain in the perineum, now? If the answer was affirmative, the pain scale was applied in order to measure intensity. Being considered as pain were the reports of pain, burning, stabbing, discomfort and discomfort in the perineal region.

The data were collected by way of interviews and consulting medical records using a structured form con-
Association between perineal trauma and pain in primiparous women

Franscisco AA, Kinjo MH, Bosco CS, Silva RL, Mendes EPB, Oliveira SMJV 
taining information identifying the participant, sociodemographic characteristics (age, ethnicity and education), information regarding the delivery (date and time of the delivery, presence of perineal trauma and suturing, type of trauma, and birth weight of the NB) and the occurrence and severity of perineal pain.

The ethnicity variable was obtained according to the woman's own statement. The number of perineal traumas was classified according to the occurrence of lesions in one or more locations (0 to 2 ), recorded in the medical record. In the event of more than one type of trauma occurring simultaneously, the most serious was considered.

For statistical analysis, the Shapiro-Wilk, chi-square, Mann-Whitney and Kruskal-Wallis tests were used. In addition to these tests, a logistic regression model was adjusted in order to evaluate independent factors associated with the presence of perineal pain. All tests were performed considering a significance level of $5 \%$.

This study was approved by the Research Ethics Committee of the School of Nursing of USP (Case No. $1119 / 2012 / C E P-E E U S P)$. The participation of the postpartum women was voluntary, after signing the Informed Consent Form.

\section{RESULTS}

The study included 473 postpartum women who were predominantly black (50.7\%), with a mean of 22 (SD = 4.8) years of age, $9.9(S D=2.0)$ years of education and 16 $(S D=11.6)$ hours postpartum. The newborn weight was on average $3,179 \mathrm{~g}(\mathrm{SD}=379 \mathrm{~g}$ - range $2,130 \mathrm{~g}$ to $4,485 \mathrm{~g})$.

The prevalence and mean intensity of pain were $33.0 \%$ and 4.7 points $(S D=2.0)$ in the numeric scale, respectively.

Seventy-one women (15.0\%) had an intact perineum. Episiotomy was the most frequent trauma (46.7\%), followed by first (32.4\%) and second (5.1\%) degree lacerations. In four of the patients' medical records the degree of perineal trauma was not found. No cases of third- or fourth-degree lacerations were recorded.

Perineal suturing was performed in $83.5 \%$ of the participants. When considering only first-degree lacerations, $96.3 \%$ of them were sutured.

When comparing women according to the occurrence of pain, there was a significant statistical difference in the perineal trauma number $(p=0.017)$ and the postpartum time $(p=0.001)$. The rate of intact perineum was higher among women without pain ( $12.3 \%$ versus $2.7 \%$ ), while those with pain had one or two perineal traumas. However, when comparing the pain complaint among women with one or two traumas, no significant difference was shown $(p=0.930)$. At the time they were interviewed, the women with perineal pain had a shorter mean length of postpartum time (12.9 and $S D=7.3$ versus 17.6 and $S D=12.9$ hours).
Regarding the type of perineal trauma, it was observed that episiotomy was more frequent among the mothers in pain, whereas among those without pain, first-degree lacerations prevailed as the most common. However, this difference was not statistically significant $(p=0.703)$.

The intensity of perineal pain was also related to the number of traumas $(p=0.027)$ and the postpartum time ( $p<0.001$ ). Postpartum women with one perineal trauma reported about four times more moderate pain than those with an intact perineum (5.6\% versus $20.7 \%$ ). Among the groups with perineal trauma, there was no significant difference in terms of pain intensity. Primiparous women with less postpartum time reported more intense perineal pain.

The logistic regression analysis showed that, compared to women with an intact perineum, the primiparous women with one or two perineal traumas were nearly three times more likely to have perineal pain. Regarding the postpartum time, it was observed that, for each hour elapsed after birth, the chance of pain occurring decreased by $4.8 \%$, being that the odds ratio for each hour elapsed was 0.952; as the coefficient of postpartum time equal to 0.048 was obtained from the difference (1-0.952) (Table 1).

Table 1 - Estimated odds ratio (OR) and confidence interval (CI) of the postpartum time and number of perineal traumas for perineum pain, according to the logistic regression model - São Paulo, 2012 and 2013

\begin{tabular}{lcc}
\hline \multirow{2}{*}{ Variable } & \multicolumn{2}{c}{ Pain } \\
\cline { 2 - 3 } & OR & CI (95\%) \\
\hline Postpartum Time & 0.952 & $0.930-0.973$ \\
Perineal Trauma Number & & \\
0 & 1 & \\
1 & 2.8 & $1.516-5.608$ \\
2 & 2.9 & $1.065-8.013$ \\
\hline
\end{tabular}

\section{DISCUSSION}

The purpose of this study was to identify the association between perineal trauma and pain in primiparous women.

The high frequency of pain and perineal trauma identified in this study strengthens the evidence that primiparity predisposes women to trauma(5,15-16) and perineal pain after childbirth(17).

The association between the occurrence of pain and the number of perineal traumas showed that women with one or two perineal traumas were nearly three times more likely to have pain than those with an intact perineum. However, it can be said that this effect was only a result of having a lesion or not, since a significant difference was not found when comparing the groups with one or more traumas. 
Pain intensity was also higher among women with perineal trauma. They reported about four times more moderate pain than those with an intact perineum. However, compared to women with perineal trauma, the frequency distribution of pain scores did not follow the expected pattern, i.e., that those with the highest number of trauma would result in higher levels of pain.

Regarding the type of trauma, we found that episiotomy stood out as the most common lesion, especially among those women who reported perineal pain. Moreover, among those without pain, first-degree laceration was predominant. However, we found no association between the type of perineal trauma and the occurrence and intensity of pain.

Yet, previous studies have indicated a direct relationship between the type of perineal trauma and pain. Episiotomy was associated with the occurrence and persistence of pain. This procedure raised the chance of perineal pain by four times and was identified as a predictive factor for pain in that region following vaginal delivery, regardless of parity ${ }^{(15)}$. Six months after delivery, episiotomy was associated with higher proportions of complaints of pain ${ }^{(11)}$.

In an Australian study regarding the intensity of pain, women with episiotomy or sutured lacerations reported more intense perineal pain than those with an intact perineum or non-sutured lacerations ${ }^{(18)}$.

In another study, a policy of selective episiotomy among primiparous women increased the possibility of maintaining the perineum intact, while routine use of this procedure significantly increased the intensity of perineal pain at 24 and 48 hours following delivery ${ }^{(10)}$.

The postpartum time also differed between the participant groups of this study. Women who reported perineal pain were in an earlier postpartum period compared to those who did not report perineal pain. The logistic regression model showed that the chance of having pain decreased almost 5\% with every hour elapsed following delivery. However, this variable refers to the time at which the participants were interviewed; thus it should be interpreted with caution, as they may not necessarily reflect, the moment in which the painful sensation began. It is noteworthy that high rates of perineal suturing were found in this study, especially in relation to first-degree lacerations. It was therefore not possible to analyze the association between this variable and the occurrence of pain. However, a randomized clinical trial demonstrated that primiparous women with first- and second-degree lacerations that were sutured had more perineal discomfort $(p=0.038)$, as compared to the non-sutured group ${ }^{(19)}$. In this sense, we question what factors influence the professional when repairing the trauma. An Australian exploratory study showed that this decision is determined by factors that include: the characteristics of the lesion, the experience of the professional, the woman's consent and the potential discomfort that this procedure can cause, among others ${ }^{(20)}$. On the other hand, in Brazil, where delivery care is characterized by authoritarian relationships between the professionals providing the obstetrical care and the women ${ }^{(21)}$, the opinion of the women is hardly ever considered.

In addition, in the institution where the study was conducted, catgut and traditional suture technique are conventionally used in perineal repair. However, two systematic reviews showed that the continuous suture technique is associated with less pain, as well as less need for analgesia and suture removal, as compared to the interrupted technique ${ }^{(22)}$, while the catgut thread increased complaints of perineal pain during the immediate postpartum period ${ }^{(23)}$.

Due to the impact of perineal trauma on maternal health during the postpartum period, including pain, its prevention is considered to be an important component when measuring the quality of obstetric care.

The frequency of these traumas varies considerably and can be attributed to factors that include maternal and fetal conditions along with the characteristics of the obstetric care. Among primiparous women, the weight of the newborn, the use of oxytocin and the semi-sitting maternal position during the second stage of giving birth were identified as risk factors for perineal trauma ${ }^{(4)}$.

Moreover, the introduction of practices aimed at protecting the perineum, such as positions other than the lithotomy position during the second stage of birth, perineal massage ${ }^{(24-25)}$, selective policy for episiotomy ${ }^{(7)}$, the hands-on and hands-off technique ${ }^{(26)}$, and selective use of oxytocin $^{(17)}$ could contribute to increased rates of perineal integrity and reduce the number of episiotomy. However, adoption of these practices requires changes in the care model and training of the professionals responsible for obstetric care.

The contrast between scientific evidence and healthcare practice is influenced by the professionals who provide the healthcare and how the care is structured in the institution.

In a study comparing perineal trauma rate of women whose birth occurred in three different environments (hospital, freestanding midwifery-led units, home birth), there was a significant association between giving birth in the hospital and having perineal trauma. Nulliparous women whose delivery was in the hospital had more episiotomies and third- and fourth-degree lacerations. On the other hand, in the extra-hospital environment, an intact perineum and second-degree lacerations of the large and small labia along with the vaginal wall were predominant ${ }^{(3)}$.
Association between perineal trauma and pain in primiparous women

Franscisco AA, Kinjo MH, Bosco CS, Silva RL, Mendes EPB, Oliveira SMJV 
In the maternity ward where this study was conducted, the model of care was structured to promote a physiological birth. According to the Cochrane Systematic Review, in this model of care there are fewer interventions and perineal lacerations and higher rates of spontaneous delivery compared with care in obstetric units ${ }^{(27)}$, but the proportion of perineal trauma indicated in the current study was high, particularly the rate of episiotomy, which was about five times higher than recommended by WHO for this parity $(10 \%)^{(28)}$.

The education and training of professionals who assist with childbirth also has an impact on handling the perineal region. Professionals may be educated to believe that interventions ensure a successful delivery; therefore, they resist changes in the standardized practices ${ }^{(29)}$. Moreover, the insecurity of professionals in implementing evidence-based practices can also be a limiting factor for healthcare changes.

A study of 338 midwives working in the UK revealed that most of these professionals felt insecure regarding performing episiotomies along with perineal assessment and repair after childbirth. Only midwives with 20 years or more of experience and those with higher levels of qualification were more likely to implement evidencebased recommendations and felt more confident about perineal care $^{(30)}$.

Changes in perineal care can be achieved through professional training based on the understanding and use of the available evidence. A study showed that a reduction in the number of episiotomies and third- and fourth-degree lacerations, as well as an increase in rates of an intact perineum, were obtained after a program of professional training in the use of evidence-based practices ${ }^{(31)}$, resulting in improvements in health care and in reducing the severity of outcomes resulting from obstetric care.

\section{CONCLUSION}

Primiparous women are subjected to a high frequency of perineal trauma, with episiotomy being most frequent. Most perineal traumas are sutured, especially the firstdegree lacerations. Perineal pain affects approximately one-third of primiparous women following spontaneous delivery and is associated with the postpartum time and the presence of perineal traumas. The chance of a primiparous woman having perineal pain is about three times higher after trauma in this region, as compared to those with an intact perineum, and $4.8 \%$ lower for each elapsed hour following delivery.

The recognition of the association between pain and the occurrence of perineal trauma in this group of women is important in order to improve obstetric care. On the other hand, the results presented here provoke reflection on the contrast between the care provided to a primiparous woman during a spontaneous delivery and the scientific evidence for procedures which can prevent perineal trauma, such as the restricted use of episiotomy, the type of perineal suture (continuous suture and the type of thread) and positions other than the lithotomy position for delivery.

\section{REFERENCES}

1. Graham ID, Carroli G, Davies C, Medves JM. Episiotomy rates around the world: an update. Birth. 2005;32(3):219-23.

2. Brasil. Ministério da Saúde; Centro Brasileiro de Análise e Planejamento. Pesquisa Nacional de Demografia e Saúde da Criança e da Mulher - PNDS 2006: Relatório final [Internet]. Brasília; 2008 [citado 2014 mar. 16]. Disponível em: http://bvsms. saude.gov.br/bvs/pnds/img/relatorio_final_pnds2006.pdf

3. Smith LA, Price N, Simonite V, Burns EE. Incidence of and risk factors for perineal trauma: a prospective observational study. BMC Pregnancy Childbirth. 2013;13(1):59.

4. Silva FMB, Oliveira SMJV, Bick D, Osava RH, Tuesta EF, Riesco MLG. Risk factors for birth-related perineal trauma: a cross-sectional study in a birth centre. J Clin Nurs. 2012;21(15-16):2209-18.

5. Riesco MLG, Costa ASC, Almeida SFS, Basile ALO, Oliveira SMJV. Episiotomia, laceração e integridade perineal em partos normais: análise de fatores associados. Rev Enferm UERJ. 2011;19(1):77-83.
6. Kropp N, Hartwell T, Althabe F. Episiotomy rates from eleven developing countries. Int J Gynaecol Obstet. 2005;91(2):157-9.

7. Carroli G, Mignini L. Episiotomy for vaginal birt. Cochrane Database Syst Rev. 2009;(1):CD000081.

8. Laine K, Skjeldestad FE, Sanda B, Horne H, Spydslaug A, Staff AC. Prevalence and risk factors for anal incontinence after obstetric anal sphincter rupture. Acta Obstet Gynecol Scand. 2011;90(4):319-24.

9. Chang SR, Chen KH, Lin HH, Chao YM, Lai YH. Comparison of the effects of episiotomy and no episiotomy on pain, urinary incontinence, and sexual function 3 months postpartum: a prospective follow-up study. Int J Nurs Stud. 2011;48(4):409-18.

10. Shahraki AD, Aram S, Pourkabirian S, Khodaee S, Choupannejad S. A comparison between early maternal and neonatal complications of restrictive episiotomy and routine episiotomy in primiparous vaginal delivery. J Res Med Sci. 2011;16(12):1583-9. 
11. Declercq ER, Sakala C, Corry MP, Applebaum S, Herrlich A. Major Survey Findings of Listening to Mothers(SM) III: New Mothers Speak Out: Report of National Surveys of Women's Childbearing Experiences. J Perinat Educ. 2014;23(1):17-24.

12. East CE, Sherburn M, Nagle C, Said J, Forster D. Perineal pain following childbirth: prevalence, effects on postnatal recovery and analgesia usage. Midwifery. 2012;28(1):93-7.

13. Beleza ACS, Ferreira CHJ, Sousa LD, Nakano AMS. Mensuração e caracterização da dor após episiotomia e sua relação com a limitação de atividades. Rev Bras Enferm. 2012;65(2):264-8.

14. Pimenta CAM, Cruz DALM, Santos JLF. Instrumentos para avaliação da dor: o que há de novo em nosso meio. Arq Bras Neurocir. 1998;17(1):15-24.

15. Francisco AA, Oliveira SMJV, Silva FMB, Bick D, Riesco MLG. Women's experiences of perineal pain during the immediate postnatal period: A cross-sectional study in Brazil. Midwifery. 2011;27(6):e254-9.

16. Landy HJ, Laughon SK, Bailit J, Kominiarek MA, GonzalezQuintero VH, Ramirez $\mathrm{M}$, et al. Characteristics associated with severe perineal and cervical lacerations during vaginal delivery. Obstet Gynecol. 2011;117(3):627-35.

17. Leeman L, Fullilove AM, Borders N, Manocchio R, Albers LL, Rogers RG. Postpartum perineal pain in a low episiotomy setting: association with severity of genital trauma, labor care, and birth variables. Birth. 2009;36(4):283-8.

18. East CE, Begg L, Henshall NE, Marchant PR, Wallace K. Local cooling for relieving pain from perineal trauma sustained during childbirth. Cochrane Database Syst Rev. 2012;(5):CD006304.

19. Lundquist $M$, Olsson A, Nissen E, Norman M. Is it necessary to suture all lacerations after a vaginal delivery? Birth. 2000;27(2):79-85.

20. Cioffi JM, Swain J, Arundell F. The decision to suture after childbirth: cues, related factors, knowledge and experience used by midwives. Midwifery. 2010;26(2):246-55.

21. de Carvalho VF, Kerber NPD, Busanello J, Goncalves BG, Rodrigues ED, de Azambuja EP. How the workers of a birthing center justify using harmful practices in natural childbirth. Rev Esc Enferm USP. 2012;46(1):30-7.
22. Kettle C, Dowswell T, Ismail KM. Continuous and interrupted suturing techniques for repair of episiotomy or second-degree tears. Cochrane Database Syst Rev. 2012;(11):CD000947.

23. Kettle C, Dowswell T, Ismail KM. Absorbable suture materials for primary repair of episiotomy and second degree tears. Cochrane Database Syst Rev. 2010;(6):CD000006.

24. Karacam Z, Ekmen $\mathrm{H}$, Calisir $\mathrm{H}$. The use of perineal massage in the second stage of labor and follow-up of postpartum perineal outcomes. Health Care Women Int. 2012;33(8):697-718.

25. Eason E, Labrecque M, Wells G, Feldman P. Preventing perineal trauma during childbirth: a systematic review. Obstet Gynecol. 2000;95(3):464-71.

26. Aasheim V, Vika Nilsen AB, Lukasse M, Reinar LM. Perineal techniques during the second stage of labour for reducing perineal trauma. Cochrane Database Syst Rev. 2011;(12):CD006672.

27. Hodnett ED, Downe S, Walsh D. Alternative versus conventional institutional settings for birth. Cochrane Database Syst Rev. 2012;(8):CD000012.

28. World Health Organization. Care in normal birth: a practical guide. Report of a Technical Working Group [Internet]. Geneva; 1996 [cited 2014 Apr 17]. Available from: http://www. who.int/maternal_child_adolescent/documents/who_frh_ msm_9624/en/

29. Diniz SG. Gênero, saúde materna e o paradoxo perinatal. Rev Bras Crescimento Desenvolv Hum. 2009;19(2):313-26.

30. Bick DE, Ismail KM, Macdonald S, Thomas P, Tohill S, Kettle C. How good are we at implementing evidence to support the management of birth related perineal trauma? A UK wide survey of midwifery practice. BMC Pregnancy Childbirth. 2012;12:57.

31. Ho JJ, Pattanittum P, Japaraj RP, Turner T, Swadpanich U, Crowther CA. Influence of training in the use and generation of evidence on episiotomy practice and perineal trauma. Int J Gynaecol Obstet. 2010;111(1):13-8. 